\title{
Analysis of the incremental cost method and the net present value method applied in the energy sector
}

\author{
Tadeusz Noch $^{1, *}$, and Zdzisław Kusto ${ }^{1}$ \\ ${ }^{1}$ Gdańsk School of Higher Education, WNI, 80-875 Gdańsk, ul. Biskupia 24B, Poland
}

\begin{abstract}
The study characterizes hybrid sources applied in the power industry, created with the use of unconventional energy sources. An example of cooperation of heat pumps and conventional sources was used. The article notes the technological progress also concerning heat exchangers. To calculate economic efficiency, the MKN Incremental Cost Method and the NPV Net Present Value method were used. The article refers to the calculation of investment outlays and operating costs and repayment of a bank loan for individual heat sources. The possibility of assuming separate values of discount rates for the installation of heat pumps and hybrid boilers as well as the comparative installation were shown. Also included is the possibility of adopting a separate discount rate for income derived from savings associated with the purchase of fuel and energy and the sale of heat to a third party consumer. The analysis covered the MKN Incremental Cost Method and the NPV Net Present Value method. The computational algorithm contains costs of hybrid installation with heat pumps and costs of a comparative conventional installation in a version without revenues and with revenues from the sale of heat. Presented is the method of calculating the net present value in the next year of operation, discounting to the zero year and observing in which year the positive value will be obtained. Economic calculations, according to popular views, are the basis for choosing the optimal heating variant. Ecological effects and social demand may provide additional separate criteria in the selection of the heating system.
\end{abstract}

\section{Introduction}

Unconventional energy sources supply heat primarily to the minor recipients. Added to conventional sources, it creates hybrid sources. For example, heat pumps may be used in cooperation with conventional sources.

\footnotetext{
* Corresponding author: tadeusz.noch@gsw.gda.pl
} 
Technological progress in recent decades has led to the miniaturization of a number of technical devices in all branches of industry. This also applies to heat pumps and heat exchangers used in industry. Heat exchangers used for cooling highly loaded electronic circuits play a special role here. In the small space of these circuits, very large heat fluxes are emitted [1]. Phenomena occurring in mini- and microchannels differ significantly from those for conventional channels. This resulted in the need to conduct basic research on the physics of the boiling phenomenon and flow hydraulics in such channels [2-5].

To calculate economic efficiency of such systems, the incremental cost method, called MKN in short and the NPV method (Net Present Value Method), are used here. The NPV method was formulated in such a way as to be fully compatible with the MKN Incremental Cost Method [6-7].

There are two versions of the formula. In the first version, the revenues accepted for the calculation are understood as a reduction in cash expenses resulting from the reduction of conventional fuel consumption after the application of heat pumps. The reduction of fuel costs in the NPV method defined in this way is equal to the difference in costs of heating variants in the MKN method. This version applies to the case in which the heat generated is not sold; it is produced solely to cover the user's needs.

The second version of the formula additionally takes into account the sale of heat to an external consumer. Here, profits from the sale of heat at a fixed price are added to the profits in the form of reduced expenses for the purchase of fuel. This price for a hybrid source with heat pumps may differ from the price of the heat sold produced in the comparative conventional source. This version of the formula takes into account the additional costs of use in the form of a tax on profits from the sale of heat.

Investment expenditures and operating costs as well as the costs of loan repayment are calculated separately for each heat source: in a hybrid system (for heat pumps and for conventional boilers cooperating with heat pumps) and for a conventional - comparative heating system.

The cost calculation assumed the possibility of adopting separate discount rates: for heat pump installations $\left(p_{p c}\right)$ and for the hybrid boiler installations $\left(p_{k h}\right)$, as well as for the comparative installation $\left(p_{k p}\right)$. The possibility of adopting a separate discount rate $\left(p_{d}\right)$ was also assumed, i.e. for income obtained from saving cash expenses for the purchase of fuel and energy resulting from the installation of heat pumps and for revenues obtained from the sale of heat to a third party consumer.

\section{Incremental cost method MKN}

The article compared the incremental costs of heating with a hybrid heat source with heating costs related to a traditional, conventional source of heat as a comparative source. The incremental cost method, modelled on the LCC method [8-9], known in the literature, is formulated in such a way that all the costs of operating the installation and bank loan repayment costs are added to the above-mentioned initial costs in the subsequent years of operation. This is described by the relations $(1) \div(7)$ for a hybrid heat source with heat pumps and relations $(8) \div(11)$ for a conventional comparative heat source [10]. 


\subsection{Costs of a hybrid installation with heat pumps}

The costs of a hybrid installation with heat pumps are as follows:

$$
\begin{gathered}
K_{M K N h j}=K_{M K N p c . j}+K_{M K N k h j}= \\
=\left(K_{i n w w d p c}+\sum_{k=1}^{j} \frac{K_{e p c k}}{\prod_{t=1}^{k}\left(1+p_{p c t}\right)}\right)+\left(K_{i n w w d k h}+\sum_{k=1}^{j} \frac{K_{e k h k}}{\prod_{t=1}^{k}\left(1+p_{p h t}\right)}\right) \\
K_{\text {inwwdpc }}=\sum_{j=-N 1}^{0} K_{i n w w p c j} \cdot \prod_{k=0}^{-j}\left(1+p_{p c k}\right)+\sum_{j=1}^{N 2} \frac{K_{i n w w p c j}}{\prod_{k=1}^{j}\left(1+p_{p c k}\right)}-D_{o t p c} \\
K_{\text {inwwdkh }}=\sum_{j=-N 1}^{0} K_{i n w w k h j} \cdot \prod_{k=0}^{-j}\left(1+p_{k h k}\right)+\sum_{j=1}^{N 2} \frac{K_{i n w w k h j}}{\prod_{k=1}^{j}\left(1+p_{k h k}\right)}-D_{o t k h}
\end{gathered}
$$

- version without revenues from the sale of heat:

$$
\begin{aligned}
& K_{\text {epck }}=Z_{\text {krpcj }}+O_{\text {prpcj }}+K_{\text {prowpc } j}+K_{\text {ezmpc } j}+K_{\text {estpc } j}+K_{\text {dodpc } j} \\
& K_{\text {ekh } k}=Z_{k r k h j}+O_{\text {prkh } j}+K_{\text {prowkh } j}+K_{\text {ezmkhj }}+K_{\text {estkh } j}+K_{\text {dodkh } j} \\
& k \equiv j, \quad j=1,2, \ldots, N
\end{aligned}
$$

- version with revenues from the sale of heat:

$$
\begin{aligned}
& K_{e p c k}=Z_{k r p c j}+O_{p r p c j}+K_{p r o w p c j}+K_{e z m p c j}+K_{e s t p c j}+P O D_{q p j}+K_{d o d p c j} \\
& K_{e k h k}=Z_{k r k h j}+O_{p r k h j}+K_{\text {prowkhj }}+K_{e z m k h j}+K_{e s t k h j}+P O D_{q h j}+K_{d o d k h j} \\
& k \equiv j, \quad j=1,2, \ldots, N
\end{aligned}
$$

where:

$D_{\text {otpc }}, D_{\text {otkh }}$ - investment subsidy for the installation of: heat pumps, hybrid boilers, PLN,

$K_{\text {epc } k}, K_{e k h k}, K_{e k p k}$ - operating costs and other running costs in the $j$-th year for the installation of: heat pumps, conventional hybrid boilers, comparative heat source, PLN/a, $j=1,2, \ldots, N$,

$K_{M K N p c j}, K_{M K N k h j}, K_{M K N k p j}$ - costs calculated incrementally for: heat pumps, hybrid boilers, comparative heat source per the $j$-th year, PLN, $j=1,2, \ldots, N$,

$K_{\text {inwwpc } j}, K_{\text {inwwkh }}, K_{\text {inwwkpj }}$ - heat pumps, hybrid boilers cooperating with heat pumps, comparative heat sources incurred in the $j$-th year, PLN/a, $t, j=-N 1, \ldots,-1,0,1$, $2, \ldots, N 2$,

$p_{p c t}, p_{k h t}, p_{k p t}-$ discount rate in a year $t$ assigned to installations: heat pumps, hybrid boilers, comparative heat sources,

$K_{\text {dodpc } j,}, K_{d o d k h j}, K_{d o d k p j}$ - unpredicted in the basic calculation algorithm, additional costs of: installation of heat pumps, hybrid boilers, comparative heat source in the $j$-th year in the period of $N$ years of operation, 
$K_{\text {estpc }}, K_{\text {estkh }}, K_{\text {estkp }}$ - fixed operating costs for the installation of: heat pumps, hybrid boilers, comparative heat source in the $j$-th year in the period of $N$ years of operation,

$K_{\text {ezmpc } j}, K_{\text {ezmkh }}, K_{\text {ezmkp } j}$ - variable operating costs for the installation of: heat pumps, hybrid boilers, comparative heat source in the $j$-th year in the period of $N$ years of operation,

$K_{\text {prowpc j }}, K_{\text {prowkh } j}, K_{\text {prowkpj }}$ - value of the repaid bank commission in the $j$-th year of operation during the loan repayment period of $N_{s b p c}$ years, taken to cover investment outlays for the installation: heat pumps, hybrid boilers, comparative heat source,

$O_{p r p c j}, O_{p r k h}, O_{p r k p j}$ - the value of the repayment of the bank loan interest in the $j$-th year of operation during the loan repayment period of $N_{s b p c}$ years, taken to cover investment outlays for the installation: heat pumps, hybrid boilers, comparative heat source,

$P O D_{q p j}, P O D_{q h j}, P O D_{q k p j}$ - tax on income from the sale of heat repaid in the $j$-th year of operation in the period of $N$ years of operation of the hybrid heat source, assigned to: heat pumps, hybrid boilers, comparative heat source,

$Z_{k r p c j}, Z_{k r k h j}, Z_{k r k p j}$ - value of the annual repayment of the bank loan in the $j$-th year of operation during the repayment of a bank loan equal $N_{s b p c}$ years, taken to cover investment outlays for the installation: heat pumps, hybrid boilers, comparative heat source.

\subsection{Costs of a comparative conventional installation}

Costs for a comparative conventional installation are as follows:

$$
\begin{gathered}
K_{M K N p j}=K_{i n w w d k p}+\sum_{k=1}^{j} \frac{K_{e k p k}}{\prod_{t=1}^{k}\left(1+p_{k p t}\right)} \\
K_{\text {inwwdkp }}=\sum_{j=-N 1}^{0} K_{i n w w k p j} \cdot \prod_{t=0}^{-j}\left(1+p_{k p t}\right)+\sum_{j=1}^{N 2} \frac{K_{i n w w k p j}}{\left(1+p_{k p t}\right)}
\end{gathered}
$$

- version without revenues from the sale of heat:

$$
\begin{array}{r}
K_{\text {ekp } k}=Z_{k r k p j}+O_{\text {prkpj }}+K_{\text {prowkpj }}+K_{\text {ezmkpj }}+K_{\text {estkpj }}+K_{\text {dodkpj }} \\
k \equiv j, t \equiv j, \quad j=1,2, \ldots, N
\end{array}
$$

- version with revenues from the sale of heat:

$$
\begin{gathered}
K_{\text {ekp } k}=Z_{k r k p j}+O_{\text {prkpj }}+K_{\text {prowkpj }}+K_{\text {ezmkpj }}+K_{\text {estkpj }}+P O D_{q k p j}+K_{\text {dodkpj }} \\
k \equiv j, t \equiv j, \quad j=1,2, \ldots, N
\end{gathered}
$$

Investment outlays are calculated as the discount sum in the year zero, in the last year before commissioning of the installation. Cash expenditures incurred in subsequent years of operation after discounting are added to the discounted sum of the investment outlay. 
Successively summed cash expenditures in subsequent years result in an incremental cost graph. An illustration of this cost variation is shown in Figure 1 [10], where:

$K_{\text {inwwd } h}, K_{\text {inwwdk }}$ - part of the investment outlay for: a hybrid heat source with heat pumps, a conventional comparative heat source; user's own contribution, values discounted to the year zero. Initial value of incremental costs for: hybrid installation, comparative source,

$K_{M K N h}, K_{M K N p}$ - the final value of incremental costs after $N$ years of operation: hybrid installation, comparative installation,

$t_{g r}$ - number of years from the project commissioning to the equalization of the incremental costs of compared investment variants,

$t_{x}$ - any period of time from the range $\{0, \mathrm{~N}\}$ years of operation, in which the difference in incremental costs is calculated $\Delta K_{M K N}$,

$N$ - computational lifetime of the project, calculated in years,

$\Delta K_{M K N}, \Delta K_{M K N 0}, \Delta K_{M K N N}-$ difference in incremental costs: at any time $t_{x}$, at the moment $t=0$, after $N$ years of operation.

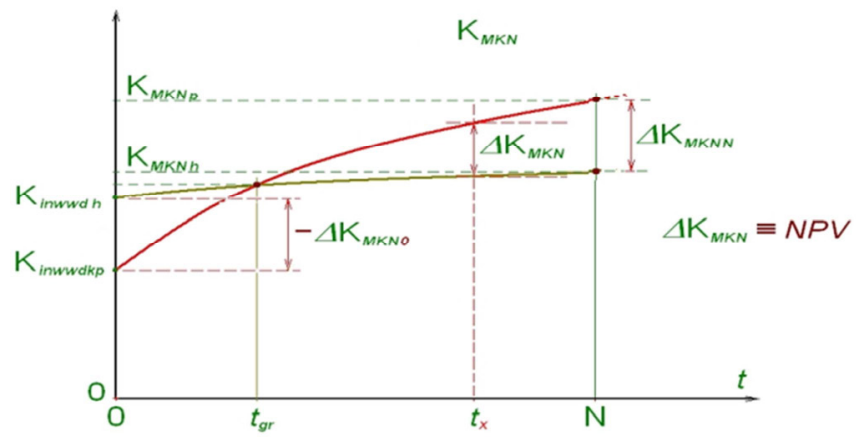

Fig. 1. A graphic illustration of the incremental cost method $K_{M K N}[10]$.

Figure 1 shows an illustration of such a case in which a hybrid heat source has higher investment outlays but much lower operating costs. Therefore, the cost increment will be equal over time $t_{g r}$. The condition of profitability is that:

$$
t_{g r}<N
$$

It is also important that the cost equalization takes place in the shortest possible time, over a period of several years. Figure 1 shows a favourable case for an unconventional heat source. This is one of many possible cases.

\section{NPV Net Present Value method}

The recipient should have a source of heat. Therefore, he can choose the installation with the best economic effects, using a comparative assessment.

When comparing investment options in terms of economic efficiency, it is essential to remember that these variants should give the same technical effects. In the case of heat sources, it must be the same amount and quality of heat generated and, if possible, comparable durability and usability of devices. In the case of investment variants with diversified technical effects, special calculation methods should be applied. One of such methods is to calculate the so-called unit cost of the product (heat) produced [10-11]. 
According to the assumptions described above, in the NPV method, monetary income is interpreted as a reduction of fuel and energy costs after the use of heat pumps. Additionally, in order to ensure the compatibility of NPV and MKN methods in the particular case, it was assumed that the initial value in the calculation of the net present value is the difference of investment expenditures, discounted to the year zero, for a hybrid heat source installation (heat pumps in cooperation with conventional water boilers) and a comparative installation with conventional boilers. This principle is illustrated in Figure 1.

In the calculation of heat production costs, as mentioned above, the assumption was to adopt separate discount rates for heat pump installations, for installations of conventional hybrid boilers and for installations of conventional comparative boilers.

The net present value in the $j$-th year of operation, discounted to the year zero, was calculated observing in which year the positive value would be obtained in the following versions:

- without revenues from the sale of heat, including relations (4), (5) and (10):

$$
N P V=
$$

$$
\begin{gathered}
=\Delta K_{i n w w}-\left[\left(\sum_{k=1}^{j} \frac{K_{e k h k}}{\prod_{t=1}^{k}\left(1+p_{k h t}\right)}+\sum_{k=1}^{j} \frac{K_{e p c k}}{\prod_{t=1}^{k}\left(1+p_{p c t}\right)}\right]-\sum_{k=1}^{j} \frac{K_{e k p k}}{\prod_{t=1}^{k}\left(1+p_{k p t}\right)}\right] \\
k \equiv j, t \equiv j, \quad j=1,2, \ldots, N
\end{gathered}
$$

- with revenues from the sale of heat, including relations (5), (6) and (11):

$$
N P V=
$$

$$
\begin{aligned}
& =\Delta K_{\text {inww }}-\left[\left(\sum_{k=1}^{j} \frac{K_{e k h k}}{\prod_{t=1}^{k}\left(1+p_{k h t}\right)}+\sum_{k=1}^{j} \frac{K_{e p c k}}{\prod_{t=1}^{k}\left(1+p_{p c t}\right)}\right]-\sum_{k=1}^{j} \frac{K_{e k p k}}{\prod_{t=1}^{k}\left(1+p_{k p t}\right)}\right]+ \\
& +\sum_{k=1}^{j} \frac{\mathrm{P}_{r z h k}-\mathrm{P}_{r z p k}}{\prod_{t=1}^{k}\left(1+p_{d t}\right)} \\
& k \equiv j, t \equiv j, \quad j=1,2, \ldots, N \\
& \Delta K_{\text {inww }}=K_{\text {inwwdkp }}-\left(K_{\text {inwwdpc }}+K_{\text {inwwdkh }}\right)=-\Delta K_{M K N 0}
\end{aligned}
$$

where:

$p_{p c t}, p_{k h t}, p_{k p t}-$ discount rate for: heat pump installations, hybrid boiler installations, comparative installation of hybrid boilers a year $t$,

$p_{d}$ - for income obtained from the savings of cash expenses for the purchase of fuel and energy resulting from the installation of heat pumps and for revenues obtained from the sale of heat to a third party consumer,

$P_{r z h k}, P_{r z p k}$ - revenues obtained from the sale of heat generated in: hybrid installation, comparative installation, PLN/a. 
Description of other variables is given in relations $(1) \div(11)$ and in the description of Figure 1.

A graphic illustration of the NPV method compatible with the MKN method is shown in Figure 2 [10]. The compatibility takes place in the case described by relation (13). In the case described by relation (14), additional profits from the sale of heat are added, which change the net present values and which are no longer equal to the difference of incremental costs.

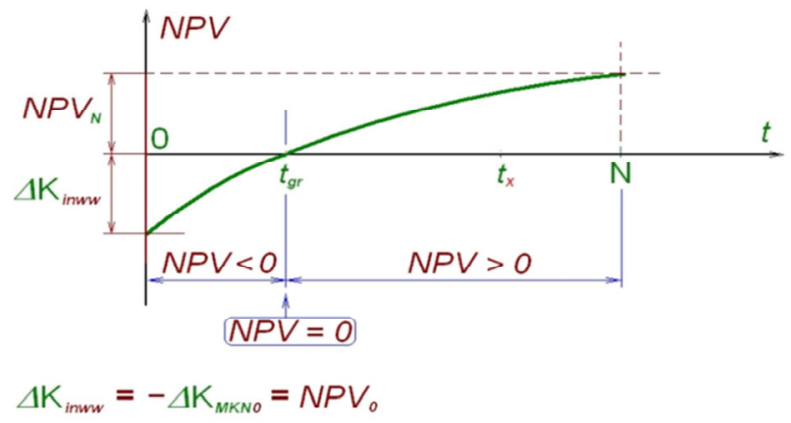

Fig. 2. Graphic illustration of the NPV method compatible with the MKN method, described by relation (13) [10].

The description of the quantities shown in Figure 2:

$N$ - computational lifetime of the project, calculated in years,

$N P V_{0}, N P V_{N}$ - net present value at the moment $t=0$, after $N$ years of operation of the project,

$t_{g r}$ - number of years from the beginning of operation of the project to the equalization of the incremental costs of compared investment variants. In time $t<t_{g r}$ the value of $N P V<0$, when $t>t_{g r}$, then the value of $N P V>0$,

$\Delta K_{\text {inww }}$ - difference in investment outlays of compared investment variants, at the same time value $N P V$ at the moment $t=0$ (initial value $N P V$ ),

$\triangle K_{M K N 0}$ - difference in incremental costs at the moment $t=0$, when the project is commissioned. It is equal to the difference of own investment contribution for a hybrid installation and for a comparative installation. It is also the initial value of $N P V$.

\section{Conclusion}

In the selection of the best investment option due to the manufacturing costs, the above-described methods are used as one of many. Particularly noteworthy are the methods for calculating unit costs of heat generation [10-11]. Economic calculations, according to popular views, are the basis for choosing the optimal heating variant. Ecological effects and social demand may provide additional separate criteria in the selection of the heating system. The choice of the optimal variant reduced only to the lowest heating costs becomes insufficient.

One of the important tasks is to provide energy security, which, like environmental requirements, reduces the consumption of conventional energy resources. In the case of heat pumps, the possibility of recovering waste heat from motors that drive a heat pump compressor must be taken into account. This is of 
particular importance in the application of high-power heat pumps powered by internal combustion engines.

In the last decade, the use of geothermal energy has been mentioned, whose resources in Poland are classified as very rich [12-14]. High-temperature geothermal water can be used directly for heating or, in the case of superheated water, for generating electricity. Low-temperature geothermal waters can be used in municipal and housing management, and in some branches of industry through properly adapted heat pumps.

\section{References}

1. M. Trela, R. Kwidziński, Zeszyty Naukowe Gdańskiej Szkoły Wyższej, 16, 333-360 (2016)

2. M. Asadi, G. Xie, B. Sunden, Int. J. Heat Mass Transfer, 79, (2014)

3. M.K. Khan, P.K. Sahoo, Appl. Therm. Eng., 29, (2009)

4. D. Del Col, A. Bisetto, M. Bartolato, D. Torresin, L. Rosetto, Int. J. Heat Mass Transfer, 67, (2013)

5. L. Saraceno, G.P. Celata, A. Furrer, G. Zummo, Int. Int. J. Therm. Sci. 53, (2012)

6. E. Ratajczak, (Elektroenergetyka polska $w$ okresie przemian, PG Wydział Elektryczny, 1993)

7. J. Górzyński, (Audyting Energetyczny, NAPE, 2002)

8. M. Świderski, (Analiza LCC (Life Cycle Cost Analysis) narzędziem wspomagajacym ocene projektów inwestycyjnych zwiazanych $z$ technika pompowa, IX Forum Użytkowników Pomp, 2003)

9. K. Palka-Wyżykowska, (Metoda LCC i jej przydatność do ekonomicznej oceny efektywności systemów energetycznych na przykładzie systemów grzewczych w budownictwie mieszkaniowym, Wydział Mechaniczny PG, 2008)

10. Z. Kusto, (Wspótpraca pomp ciepła ze źródtem konwencjonalnym. Algorytmy obliczania bilansu energetycznego i efektywności ekonomicznej, 2009)

11. Wykorzystanie programu SAFIRE do opracowania scenariuszy rozwoju energetyki odnawialnej w Polsce do roku 2020 (ECEO IBMiER, 2001)

12. J. Sokołowski, K. Mrozek i inni, (Atlas geosynoptyczny. Arkusz Warszawa Zachód. Geosynoptyka i Geotermia, 5, 1995)

13. M. Jędrysek, (Geotermia w Polsce. Wybrane zagadnienia z punktu widzenia Głównego Geologa Kraju. Kongres Geotermalny, MŚ, 2006)

14. J. Kapuściski, A. Rodzoch, (Geotermia niskotemperaturowa w Polsce. Stan aktualny i perspektywy rozwoju, MŚ, 2006) 